\title{
Actors and governance in the transition toward universal electricity access in Sub-Saharan Africa
}

\author{
Anteneh G. Dagnachew ${ }^{\mathrm{a}, \mathrm{b}, *}$, Andries F. Hof ${ }^{\mathrm{a}, \mathrm{b}}$, Mark R. Roelfsema ${ }^{\mathrm{a}}$, Detlef P. van Vuuren ${ }^{\mathrm{a}, \mathrm{b}}$ \\ ${ }^{a}$ PBL Netherlands Environmental Assessment Agency, The Hague, the Netherlands \\ ${ }^{\mathrm{b}}$ Copernicus Institute of Sustainable Development, Utrecht University, the Netherlands
}

\section{A R T I C L E I N F O}

\section{Keywords:}

Universal electricity access

Off-grid

Sub-Saharan Africa

Governance

\begin{abstract}
A B S T R A C T
Sub-Saharan Africa faces several challenges that hamper the effort to provide universal electricity access. The challenges are not the result of lack of energy resources but rather the result of governance and institutional problems as well as lack of capital to meet the high investment requirement. This study aims to provide relevant policy recommendations to facilitate the path towards universal electricity access in Sub-Saharan Africa. We do this by identifying the barriers for electricity access and the relevant actors, institutions, and regulations using desk research, stakeholder interviews and expert workshops. The results show that the absence of overall plans and approaches and lack of clarity in policies are the main challenges for the sector. Setting standards for electricity products, such as solar panels, could help to reduce the problem of counterfeit poor quality products. A broader participation of non-governmental actors is needed to increase the speed of electrification. This requires innovative revenue schemes, financial and fiscal incentives and elimination of market distortions. More generally, we conclude that stable and consistent policy frameworks and improved coordination between actors, are crucial to accelerate electrification in the region.
\end{abstract}

\section{Introduction}

Several governments in developing countries have emphasized the crucial role of electricity for human development (Parshall et al., 2009) and have, therefore, put electrification as a development priority (Scott and Seth, 2013; APP, 2015; Deshmukh et al., 2013). Despite this, most business-as-usual or current policy projections do not expect the absolute number of people with no access to electricity to decline significantly between now and 2030 (IEA, 2019; Dagnachew et al., 2017). Sub Saharan Africa (SSA) represents a primary example of this: while more than 600 million people in SSA did not have access to electricity in 2010, in 2018 that number had barely declined (IEA, 2019).

The challenges in SSA are not the result of lack of energy resources. The region has ample fossil and renewable energy resources to meet the demand. Recoverable oil resources will be sufficient for the next 100 years, coal for over 400 years and gas for about 600 years (IEA, 2014), while the region as a whole has also abundant potential for solar, wind and hydropower (Hoogwijk, 2004; IRENA, 2012). Rather, the challenges are a result of governance and institutional problems, as well as lack of capital to meet the high investment requirement. Monopoly (Turkson and Wohlgemuth, 2001), corruption (World Bank, 2009) and inefficient management (Scott, 2015) are some of the challenges mentioned in the literature. As a result, the energy system functions poorly with an unstable and unreliable electricity supply, low generation capacity, low efficiency, inadequate investment, high costs and often prices that are too low to cover costs (Sokona et al., 2012; Joskow, 2006).

Several studies have examined the governance of the electricity system and the energy transition in SSA countries. Power et al. (2016) studied the involvement of Brazil, India and China in the transfer of renewable energy technologies and their overall significance in the energy systems of Mozambique and South Africa. Newell and Phillips (2016) explored the theoretical and practical challenges of energy transition in Kenya through an account of the political economy of energy transitions and the ways in which they are constrained and enabled by neo-liberalization processes. Baker et al. (2014) discussed the governance and financing of clean energy transition in South Africa by analysing the struggle over competing energy visions, infrastructures and political agendas (Winkler, 2005). examined various policy options for promoting renewable electricity and the implementation challenges in South Africa (however, without addressing the individual actors or their networks).

The above-mentioned studies all focused on actors and processes

\footnotetext{
* Corresponding author. PBL, PO Box 30314, 2500 GH, The Hague, the Netherlands.

E-mail address: Anteneh.dagnachew@pbl.nl (A.G. Dagnachew).
} 
either in their current status or in the context of the transition towards a low-carbon energy system. This paper, on the other hand, focuses on a transition towards universal electricity access, while taking the regional socio-economic differences into consideration. More specifically, the aim of this study is to provide relevant policy recommendations to facilitate the path towards universal electricity access by identifying the barriers and relevant actors, institutions, and regulations for universal electricity access in different regions in SSA. Given the crucial role that they play in providing universal access to electricity, the focus of the study specially lies in offgrid systems. Our analysis is based on a desk research, workshops and expert interviews in the case study countries Ghana, Nigeria, Ethiopia, and Tanzania. The desk research was aimed at providing a broad picture of governance of electricity systems in SSA and provided input to the workshops. The workshops aimed to narrate possible pathways for electrification in SSA, identify the actors and explain their role in the system. The results of the workshops were also used to structure the interviews and further analysis.

The rest of the paper is organised as follows. Section 2 provides the methodology used for the expert workshops and stakeholder interviews employed in the case-study countries. Section 3 presents a general discussion of important aspects related to actors involved in the governance of electricity supply, with special focus on barriers for off-grid electrification in SSA. It thereby provides a general framework to structure and analyse the results. Section 4 discusses the results in terms of alternative electrification storylines, institutional structure and actors, and regulatory instruments. Section 5 presents the discussion, followed by conclusion and policy recommendations in section 6 .

\section{Methodology}

We first conducted a desk research to identify the relevant actors in electricity governance and identify barriers that hinder the expansion of decentralized systems in developing countries. This provided the basis for the expert workshops that were organised to develop a set of narratives for electricity production and governance in SSA. These narratives were then used as context for the stakeholder interviews and the analysis. The results from the stakeholder workshops and the stakeholder interviews were used to provide relevant policy recommendations.

\subsection{Expert workshops}

Three workshops were held in the Netherlands and in Ethiopia to create qualitative storylines that describe the roles of different actors in the transition to sustainable and universal electricity access in SSA (see section 4.1 for results). The expert workshops involved several experts who are familiar with the region's electricity sector and included policy makers, researchers, financers, modellers, energy service providers, Non-Government Organizations and the private sector. The narratives describe the main characteristics of the possible future evolution of the electricity sector in the region. These serve as the context for stakeholder interviews, to understand the barriers, and identify the gaps in governance of the sector in the region. The list of organizations involved in the workshops is presented in Annex 1.2 of the supplementary information (SI).

The aim of the first workshop was to explore various storylines for electricity production and governance together with other modellers and researchers. The purpose of the second and third workshops was to further develop the storylines and complement the quantitative pathways presented in Dagnachew et al. (2017) and Dagnachew et al. (2018) with qualitative storylines that describe the roles of different actors in the transition to sustainable and universal electricity access in SSA. In these two workshops, we employed the world-café model to create a hospitable space, encourage everyone's contribution, and connecting diverse perspectives on the issue. At the end of the third workshop, key actors and their roles were identified, as well as driving forces and key uncertainties. These served as the basis for storylines that were developed to structure and validate stakeholder interviews and to narrate possible future paths for the region's electricity sector. The storylines show how old and new actors and their roles could evolve in the future.

\subsection{Stakeholder interviews}

The storylines provide the structure and the context for the stakeholder interviews. The aim of the interviews was to identify existing actors, institutions and regulations and their interactions in Nigeria, Ghana, Ethiopia, and Tanzania as narrated in the storylines. Stakeholder interviews were conducted for different electrification projects (see Annex 2.2 and 2.3 in SI for list of interviewees and interview questions). In addition to the central grid, we identified off-grid projects through iterative discussions with experts, where large numbers of off-grid electrification projects are being implemented. The selected countries capture the diversity in population size, economic development, natural resource availability, and governance culture. The choice is also influenced by the ease of access to local information. The list of organizations participated in the interview is presented in Annex 2.3 of the SI.

A total of 100 interviews were conducted between August and October 2017. After identifying the projects, actors including national governments, regional/state governments, local governments, key financial institutions, civil society organizations, academic institutions and the private sector were approached for interviews. The interviews were semi-structured open-ended, and were based on pre-determined questions, which allowed stakeholders to share the requested information (Annex 2.2 of the SI presents the interview questions). In developing the question, we tried to identify the most appropriate way to obtain the necessary information together with local experts, given the cultural context. The interview questions were tested with non-priority stakeholders in each country.

The initial process resulted in a long list of actors involved in the sector and we prioritised the ones that play a crucial role in the sector. For this, we consulted at least one expert in each country with good knowledge of the electricity sector, its actors, and the power of those actors to influence policy. Following that, we applied snowball sampling to identify and include actors deemed important by respondents. The snowballing helped to identify actors that play important roles in centralized and decentralized systems. This process provided an extensive list of actors in the electricity sector in the countries under consideration.

We conducted interviews with stakeholders of three types of electrification projects in each country: the central grid, a mini-grid system, and a stand-alone system. The projects were selected based on discussions and recommendations from local experts. Below, the projects/ systems are briefly introduced.

\subsubsection{Central grid projects}

Ghana has a total installed capacity of about $4.4 \mathrm{GW}$, coming from hydropower and fossil fuel-based thermal plants (Gyamfi et al., 2018). Volta River Authority (VRA) generates the bulk of the electricity. The transmissions network in Ghana is owned and operated by the Ghana Grid Company Limited (GRIDCo), while Electricity Company of Ghana (ECG) and Northern Electricity Distribution Company (NEDCo) dominate the distribution of electricity. The interview is conducted with stakeholders in Accra, Ghana.

The total installed electricity capacity in Nigeria is $12.5 \mathrm{GW}$, mostly coming from fossil-based thermal plants and hydropower. However, mostly, only half this capacity is available (Aliyu et al., 2013). The Nigerian Electricity Regulatory Commission (NERC) is an independent regulatory body responsible for the technical and economic regulation for the Nigeria Electricity Supply Industry (NESI). NESI consists of six generation companies, one transmission company and eleven distribution companies. Stakeholders in Lagos Mainland were chosen for the interview. 
Ethiopia has an installed capacity of $4.2 \mathrm{GW}$ (Azerefegn et al., 2020), of which $90 \%$ consisting of hydropower. The rest of the capacity consists of wind and fossil fuel-based thermal plants. The Ethiopian Electric Power (EEP) is responsible for constructing and administration of power generation plants, high voltage transmission lines, substations and whole sale of electricity. The Ethiopian Electric Utility (EEU) is responsible for the power distribution and the operation of power transmission lines of $\leq 66 \mathrm{kV}$ within the national power grid. The interviews were conducted with stakeholders in Addis Ababa, Ethiopia.

Tanzania has $1.6 \mathrm{GW}$ installed capacity. The majority of the electricity $(>1 \mathrm{GW})$ is produced from thermal plants, with the remainder consisting of hydro (561 MW) and other renewables (Eberhard et al., 2016). Despite repeated attempts to reform the sector, it still lacks sustained commitment to private sector investment. The Ministry of Energy and Minerals (MEM) is responsible for overall energy policy formulation, while an independent regulatory agency, the Energy and Water Utilities Regulatory Authority (EWURA), dictates the regulation of the sector. The interviews are conducted with stakeholders in Arusha, Tanzania.

\subsubsection{Mini-grid projects}

In Nigeria, a natural gas based mini-grid system - the mainland independent power project - to alleviate the problem of frequent power interruption was selected. This project with a capacity of $8.8 \mathrm{MW}$ was established by the Lagos state government and provides electricity to 12,000 residents in Lagos Mainland. The project consists of a publicprivate partnership between the Mainland Power Limited (part of Lagos state government), the CET Energy (a private energy group managing the system), and Skye Bank that financed the project. In Ethiopia, a diesel powered mini-grid that supplies electricity to a rural settlement in Gambella was selected. The system has $6 \mathrm{MW}$ of installed capacity and serves 20,000 residents. In Ghana, the Ghana Energy Development and Access Project (GEDAP) was selected. This project implemented a total of five solar PV and wind powered mini-grids with a total capacity of $200 \mathrm{~kW}$, supplying around $650 \mathrm{kWh}$ of electricity per day. In Tanzania, we chose the JUMEME Rural Power Supply (JUMEME) project in Bwisya Village of Mwanza Region. The projects consist of a 60 kWp solar PV and a 33-kVA diesel generator hybrid mini-grid system built with the financial support from the Sustainable Energy Fund for Africa (SEFA).

\subsubsection{Stand-alone projects}

The stand-alone projects were all related to solar home systems. In Nigeria, the Lagos Solar project was selected, which consists of a partnership between Lagos State Electricity Board (LSEB) and Solar Nigeria, which is financed by UK Department for International Development (DFID). The project provides access to electricity to schools and health centres in rural and peri-urban areas of Lagos State. In addition to providing half of the required investment, LSEB provides training programmes to locals on operation and maintenance of the system. In Ethiopia, the Solar Energy Foundation project, which operates under the rural electrification programme and targets households in remote rural areas with heavy reliance on kerosene lamps, was chosen. The foundation works together with governments, NGOs, training institutes and solar home system manufacturers in Ethiopia. In addition to providing finance, it also provides trainings for locals in operation and management of the system. In Ghana, the Ghana National Rooftop Solar Programme was selected as an interesting case to study stand-alone electrification in the country. In 2015, the Ministry of Energy through the Energy Commission launched the programme as an integral part of the government strategy to expand access to electricity. The programme consists of a capital subsidy on solar systems to help make solar affordable for the average Ghanaian. The National Rural Electrification Program (NREP) of Tanzania is a government program that aims to expand rural electrification by working together with the private sector. Mobisol provides large productive-use solar home systems under this program, combining them with mobile technology and a 36-month micro finance scheme.

\section{Access to electricity: key actors and barriers}

This section presents a general framework of actors and institutions involved in electricity governance based on the conducted desk research. We also introduce known barriers to off-grid electrification systems that are deemed crucial to provide access to electricity in remote, low density settlements. The findings are used to structure the workshops and stakeholder interview as well as for framing of the analysis.

\subsection{Actors in the governance of electricity supply}

Governance issues are often cited as being the root cause of electricity access problems. Governance in the energy sector refers to the actors, institutions and processes that shape how decisions are made in the process of providing energy services (Wade et al., 2013). It involves a broad spectrum of actors connected to energy infrastructure and energy services. These actors include (local and national) governments, NGOs, civil society groups, corporations, residents, as well as new actors.

The actors involved in the governance of the electricity sector are strongly influenced by the technical setting of the electricity system (Lammers and Diestelmeier, 2017). In general, there are two approaches to electrification: a centralized (on-grid) track and a decentralized (mini-grid and off-grid) track, though they might have their own variants. These tracks of electrification can be defined based on the type of technology used and the institutions involved (Tenenbaum et al., 2014). Centralized tracks rely on electricity generation at large-scale centralized facilities and subsequent distribution through a transmission network with the government as the main actor. In this system, electrification is undertaken by national governmental entities such as the state-owned national utility, a rural electrification agency (REA), or the ministry of energy, acting alone or together with the extension of the national grid as the main route for increasing access (Tenenbaum et al., 2014). Decentralized tracks often refer to systems that generate electricity at or near demand sites and do not require significant distribution networks. These are usually implemented through non-governmental entities such as cooperatives, community user groups, or a smaller private sector (Koirala et al., 2016).

Integrating decentralized electrification technologies within the energy system could play an important role in increasing access, especially in rural SSA (Pachauri and BREW-Hammond, 2012). However, the policy, financial and institutional challenges of renewable energy based decentralized systems are quite different to those of centralized systems, calling for new and innovative modes of governance (Lammers and Diestelmeier, 2017).

\subsection{Barriers to off-grid (renewable) electrification}

Off-grid electrification systems are crucial in providing access to electricity, especially to the rural poor (IEA, 2017; Dagnachew et al., 2017; Dagnachew et al., 2018). However, off-grid systems face various barriers for penetration in developing countries (Yaqoot et al., 2016; Chaurey and Kandpal, 2010; Shi et al., 2016). The barriers discussed below are strongly related to the roles taken by electricity system actors, their organizational capacity, and the level of coordination between them. Below, we shorty discuss these barriers, with Fig. 1 providing the summary.

\subsubsection{Market failure}

In many countries, government-owned utilities still control electricity production, transmission and distribution. This results in a highly controlled energy sector with restricted access to technology and a lack of competition. High transaction costs and missing market infrastructure 


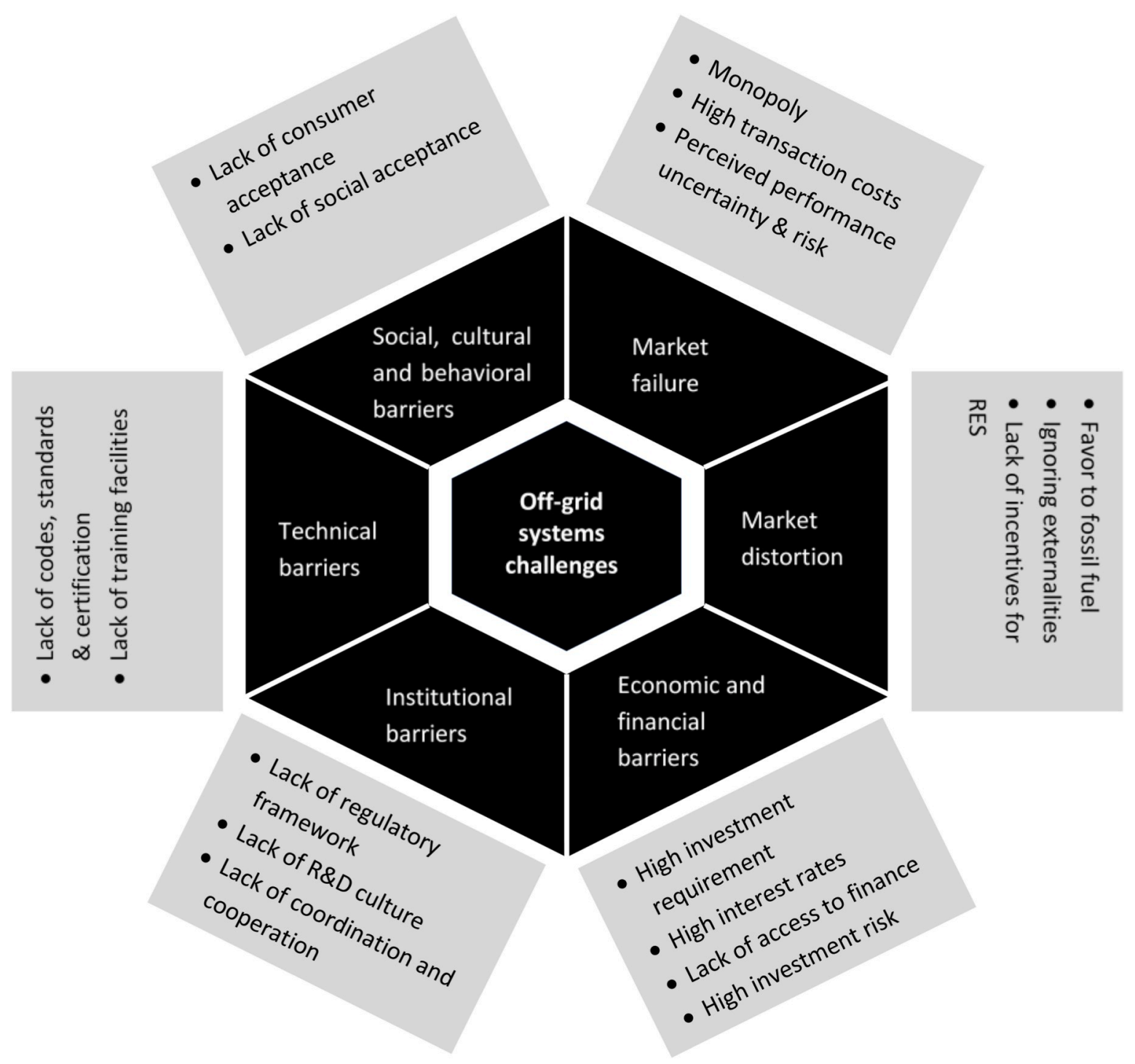

Fig. 1. Barriers to off-grid electrification in developing countries (Source: authors' compilation).

have been mentioned as barriers to renewable energy based decentralized systems (Yaqoot et al., 2016). In addition, lack of information about new technologies results in uncertainty about the quality and efficiency of decentralized energy technologies. Lack of information among the stakeholders has been cited in many studies (Yaqoot et al., 2016; Winkler et al., 2017) as one of the barriers to the successful dissemination of decentralized systems. Consumers perceive new technologies to be more expensive than traditional systems and involve more financial and investment risks.

\subsubsection{Market distortion}

Fossil fuel use has large negative external effects related to human health, ecosystem decline and climate change. In most developing countries, these negative external effects are not internalised in their costs. On the contrary, there are often large public subsidies, both implicit and explicit, channelled in favour of fossil energy sources (Whitley and van der Burg, 2015). This distorts investment decisions by significantly lowering energy prices from fossil fuel resources. Furthermore, unequal tax burdens on fossil fuel and renewable energy industries and lack of incentives for renewable energy technologies are barriers for small- and medium-scale decentralized energy systems (Rai et al., 2016; Bhattacharyya, 2013).

\subsubsection{Economic and financial barriers}

It is difficult for developers to obtain long-term credits for off-grid projects with acceptable conditions (Clean, 2015). One reason is the small scale of many decentralized renewable energy projects. Many large financial institutions are unwilling to consider small projects as investing in utility-scale projects offers better returns from loans and lower transaction costs. At the same time, microfinancing institutions offer loans at very high interest rates that scare off small scale investors. High risk perceptions, which can be influenced by factors such as policy design, sudden policy changes, permitting procedures etc., make investment in decentralized electricity options unattractive to private investors. This hinders access to finance from the private sector (Hussain, 2013). There are few multilateral and bilateral initiatives that provide financial resources for renewable energy projects, such as the UN Sustainable Energy Fund for Africa (SEFA), the IRENA Africa clean energy corridor, the U.S. Power Africa initiative, the Climate Investment Funds (CIF), and the EU's Electrification Financing Initiative (ElectriFi). However, the investments that these initiatives generated have been far below needs (Gujba et al., 2012). Moreover, the initiatives are fragmented, causing overlaps, inefficiencies and overall higher transaction costs (Tagliapietra and Bazilian, 2017). 


\subsubsection{Institutional barriers}

Regulatory and institutional barriers can impede deployment of offgrid technologies. Lack of clear national strategies for the energy sector, uncertainties surrounding subsidies (continuation or phase-out) and government support of both renewable energy technologies as well as fossil-based energy technologies strengthens reluctance of the private sector to invest in decentralized systems. Similarly, uncertainties in grid extension plans and regulatory requirements, and lack of coordination and cooperation within and between institutes and stakeholders involved in the sector also present challenges for private investors. Experience in India shows that extension of the central grid to rural areas have often led to end-users abandoning the use of micro/mini grids (Clean, 2015). Hence, most developing countries require a significant amount of regulatory and financial reforms to remove such institutional barriers.

\subsubsection{Technical barriers}

Technical or technological barriers generally include barriers associated with resource, technology and skill attributes. New technologies and systems are seldom on an equal footing with established technologies. There is a lack of knowledge and skills for designing, commissioning and operating decentralized renewable energy-based power plants. Inappropriateness of the identified technology, poor design, and lack of community training on the operation and maintenance of the equipment have been mentioned as barriers to the dissemination of renewable energy based decentralized systems (Yaqoot et al., 2016).

\subsubsection{Social, cultural and behavioural barriers}

When appropriate community education is missing, communities may develop negative perceptions about the functioning of the new technology (Yaqoot et al., 2016). Moula et al. (2013) recognise social acceptance as an important issue shaping the widespread implementation of renewable energy technologies and argue that 'social attitudes' need to change for radical implementation of renewable energy technologies.

\section{Results}

This section presents the result of our study. First, the storylines which were developed during the expert workshops are discussed. Then, the findings of the stakeholder interviews related to institutional structure, actors and regulatory instruments in the electricity system are provided. As mentioned before, the storylines describe how the role of actors and institutions could evolve in the future. They help identify the actors, institutions and regulations that are crucial where the development of decentralized systems is at the heart of the strategy to provide universal access to electricity. Then, in combination with the current state of affairs as established through the interviews, we identify the gaps and draw down relevant policy recommendations to facilitate the path towards universal electricity access in SSA.

\subsection{Storylines}

Based on results from the interactive discussion of the three workshops, four alternative storylines for the electricity production and governance in SSA were developed. The workshop participants identified the drivers of change and their interactions in the electricity system in SSA. The main characteristics of the storylines are organized along two axes: governance structures and electrification systems. The governance axis represents the hierarchy of decision making, the electrification system axis the dominance of large-scale on-grid systems or small-scale off-grid options. These storylines help to understand the causal relationships within the electricity system and envision various ways of future developments in the system.

Storyline-1: Top-down governance and centralized electricity production.
In this storyline, large scale on-grid systems are preferred and electrification occurs primarily through extension of the centralized grid. Electricity supply is based on the notion that state-owned monopolies or a few large utility companies provide electricity infrastructure services and distribution. Overarching strong top-down governance institutions are the norm, and the process is led by the government through organizations such as state utilities, electrification agencies or energy ministries. The national government provides rules and regulation to create a good competitive market. The private sector is given the opportunity to engage in large-scale production. Financing is (currently) not a major obstacle, as financing a few large-scale investments is generally easier than financing many smaller-scale investments. Development banks and the central government play an important role in providing or facilitating access to financing. The role of NGOs is limited to agenda setting and providing an overview of the process.

Storyline-2: Top-down governance and decentralized electricity production.

Decentralized off-grid options provided through specialized institutes such as rural electrification agencies are dominant in providing access to electricity, through market development involving private sector and others. Large donor organizations like the World Bank and the African Development Bank play a central role in providing loans and financial support through the rural electrification agencies to alleviate financial barriers. Finance is organized for the whole electricity chain and financial activities are clustered. NGOs assist in capacity building, including productive end-use promotion, standardization and certification processes. Finally, other top-down actors that are not directly involved in the energy sector, like the World Health Organization (WHO), play important roles in providing leadership, shaping the research agenda, and setting norms and standards for health-related key electricity access indicators. In this storyline, the electrification process harnesses local entrepreneurial talent (mostly as operators) and benefits from a strict governmental control.

Storyline-3: Bottom-up governance and decentralized electricity production.

In this storyline, decentralized systems (mini-grid and standalone) are preferred. Electrification is basically a community driven model and it is generally carried out through nongovernmental entities such as cooperatives, community user groups, or private entrepreneurs. To overcome potential social and cultural barriers, the needs of the electricity service user are put central and the focus is on energy services and their components. The process is inclusive, involving every stakeholder from beginning to end. This system stimulates social innovations and requires a decentralized multi-layered governance system - addressing both institutional and technical barriers. The role of the government is mainly on setting standards and regulation. But this requires capacity building within government offices and sharing experiences of best practices. Governments promote and lead the initiative to adopt new technologies and to provide confidence to the private sector through regulation, incentives and guarantees. NGOs and academia have important roles in conducting research and case studies, pilot and demonstration projects, and lead stakeholder discussions. They also take part in building local capacity, awareness creation, networking and experience sharing. However, they do not provide free money to the community, as this will distort the market and undermine ownership. The private sector is the service provider and collaborates with other stakeholders to develop innovative financing mechanisms and business models. The government provides collateral for households with difficulty to acquire financing. The community is the owner of the technology.

Storyline-4: Bottom-up governance and centralized electricity production.

Large scale on-grid systems are preferred. Electrification is generally carried out through nongovernmental entities such as cooperatives, community user groups or private entrepreneurs. Full-service contracts are delivered by (local) SME's. Their deployment especially requires 
strong organization of local communities. The national government has an enabling and facilitating role in creating a long-term perspective, by putting it on the national agenda and by creating a fair market. The local government role is to protect the community interest, make sure there are quick solutions and take care of monitoring of the project. NGOs, together with business and academia, are involved in doing research \& case studies and conduct pilot $\&$ demonstration projects. They also take part in awareness creation. These projects are especially relevant for creating confidence and making sure good quality, locally fit technologies are used. Users are willing to accept the system but require reliability/security of the service. Financing can be arranged by upscaling micro-finance or by setting up local cooperation.

\subsection{Institutional structure, actors and barriers}

Through interviews with stakeholders, the important actors involved in centralized and decentralized electrification programs in the four countries were identified. While the type and roles of actors differ by country and by project, governments have a strong presence in all the cases. Table 1 presents the key characteristics of the case-study countries relevant for understanding current electrification levels and for the choice of electrification systems.

\subsubsection{Actors and barriers in the on-grid (centralized) system}

Table 2 Presents the main actors and institutions involved in governing the current electricity sector in the case-study countries.

Generally, electrification has been a supply driven process taken by a single public utility with a top-down governance. In all our case-study countries, the electricity sector is quite similar to the system described under storyline- 1 but it is going through a reform process. However, the timing and extent of these reforms differ by country. Most are still stuck in the initial stages of reforms, which in practice implies unbundling of generation, transmission, and distribution. Nigeria is the only country where power generation within the central grid is privatised. To decrease financial risks for power generation companies, the Nigerian Bulk Electricity Trading Plc (NBET) was established as a credible offtaker (as part of the power purchase agreement (PPA)). Power distribution in Nigeria is fully privatised with 11 private companies involved in distribution. Ghana's Enclave Power Company is a private sector involved within the country's central grid system with responsibility to distribute for the Free Economic Zone. In Ethiopia and Tanzania, all components of the central grid are owned and operated by the government. The sector in all four countries is characterized by big loses in transmission and distribution that results in a sector wide revenue gap, increasing the risk for private sector participation. Other problems of the

Table 1

Key characteristics of the case-study countries in 2016 (World Bank, 2017).

\begin{tabular}{|c|c|c|c|c|}
\hline & Nigeria & Ghana & Ethiopia & Tanzania \\
\hline Sub-region & $\begin{array}{l}\text { Western \& } \\
\text { central } \\
\text { Africa }\end{array}$ & $\begin{array}{l}\text { Western \& } \\
\text { central } \\
\text { Africa }\end{array}$ & $\begin{array}{l}\text { Eastern } \\
\text { Africa }\end{array}$ & $\begin{array}{l}\text { Southern } \\
\text { Africa }\end{array}$ \\
\hline Population (million) & 186 & 28 & 102 & 56 \\
\hline $\begin{array}{l}\text { GDP (current USD in } \\
\text { billion) }\end{array}$ & 405 & 55 & 74.3 & 49.8 \\
\hline $\begin{array}{l}\text { GDP per capita PPP } \\
\text { (current USD) }\end{array}$ & 5867 & 4294 & 1735 & 2787 \\
\hline $\begin{array}{l}\text { Urban population (\% } \\
\text { of total) }\end{array}$ & 49 & 55 & 20 & 32 \\
\hline $\begin{array}{l}\text { Access to electricity } \\
\text { (\% total } \\
\text { population) }\end{array}$ & 58 & 78 & 27 & 16 \\
\hline $\begin{array}{l}\text { Rural access to } \\
\text { electricity (\% rural } \\
\text { population) }\end{array}$ & 39 & 63 & 12 & 4 \\
\hline $\begin{array}{l}\text { Population density } \\
\text { (people } / \mathrm{km}^{2} \text { ) }\end{array}$ & 204 & 124 & 102 & 63 \\
\hline
\end{tabular}

Table 2

Key actors, institutions and their roles in on-grid electrification.

\begin{tabular}{|c|c|c|c|c|}
\hline $\begin{array}{l}\text { Roles/ } \\
\text { responsibilities }\end{array}$ & Nigeria & Ghana & Ethiopia & Tanzania \\
\hline $\begin{array}{l}\text { Company } \\
\text { name }\end{array}$ & $\begin{array}{l}\text { Nigeria } \\
\text { Electricity } \\
\text { Supply } \\
\text { Industry } \\
\text { (NESI). }\end{array}$ & $\begin{array}{l}\text { Electricity } \\
\text { Company of } \\
\text { Ghana ltd. } \\
\text { (ECG) }\end{array}$ & $\begin{array}{l}\text { Ethiopian } \\
\text { Electric Power } \\
\text { Corporation } \\
\text { (EEPCo) }\end{array}$ & $\begin{array}{l}\text { Tanzania } \\
\text { Electricity } \\
\text { Supply } \\
\text { Company } \\
\text { (TANESCO) }\end{array}$ \\
\hline $\begin{array}{l}\text { Reform start } \\
\text { date }\end{array}$ & 2000 & 1994 & 2013 & 2008 \\
\hline Generation & $\begin{array}{l}\text { Six } \\
\text { generation } \\
\text { companies } \\
\text { (gencos) } \\
\text { operating as } \\
\text { private } \\
\text { entities }\end{array}$ & $\begin{array}{l}\text { The Volta } \\
\text { River } \\
\text { Authority } \\
\text { (VRA), } \\
\text { owned by the } \\
\text { government, } \\
\text { is the only } \\
\text { power } \\
\text { producer }\end{array}$ & $\begin{array}{l}\text { Ethiopian } \\
\text { Electric Power } \\
\text { Office (EEPO), } \\
\text { a state-owned } \\
\text { entity, is } \\
\text { responsible } \\
\text { for generation } \\
\text { and } \\
\text { transmission, }\end{array}$ & $\begin{array}{l}\text { Tanzania } \\
\text { Electricity } \\
\text { Supply } \\
\text { Company } \\
\text { (TANESCO) } \\
\text { is still a } \\
\text { vertically } \\
\text { integrated } \\
\text { monopoly }\end{array}$ \\
\hline Transmission & $\begin{array}{l}\text { A single } \\
\text { state-owned } \\
\text { transmission } \\
\text { company } \\
\text { (TCN) }\end{array}$ & $\begin{array}{l}\text { GRIDCo, a } \\
\text { state } \\
\text { company, } \\
\text { owns and } \\
\text { operates the } \\
\text { transmission } \\
\text { grid }\end{array}$ & $\begin{array}{l}\text { leasing of } \\
\text { transmission } \\
\text { lines and sale } \\
\text { of bulk power }\end{array}$ & \\
\hline Distribution & $\begin{array}{l}\text { Eleven } \\
\text { distribution } \\
\text { companies } \\
\text { (discos) } \\
\text { operating as } \\
\text { private } \\
\text { entities }\end{array}$ & $\begin{array}{l}\text { Two public } \\
\text { companies } \\
\text { (ECG \& } \\
\text { NEDCo) and } \\
\text { a private } \\
\text { company } \\
\text { (Enclave } \\
\text { Power } \\
\text { Company) }\end{array}$ & $\begin{array}{l}\text { Ethiopian } \\
\text { Electric Utility } \\
\text { (EEU), state- } \\
\text { owned }\end{array}$ & \\
\hline Privatization & $\begin{array}{l}\text { Power } \\
\text { generation } \\
\text { and } \\
\text { distribution }\end{array}$ & $\begin{array}{l}\text { Power } \\
\text { distribution } \\
\text { is partly } \\
\text { privatised }\end{array}$ & None & None \\
\hline $\begin{array}{l}\text { Regulatory } \\
\text { body }\end{array}$ & $\begin{array}{l}\text { The Nigerian } \\
\text { Electricity } \\
\text { Regulatory } \\
\text { Commission } \\
\text { (NERC) }\end{array}$ & $\begin{array}{l}\text { The Energy } \\
\text { Commission } \\
\text { (EC) }\end{array}$ & $\begin{array}{l}\text { The Ethiopian } \\
\text { Energy } \\
\text { Authority } \\
\text { (EEA) }\end{array}$ & $\begin{array}{l}\text { The Energy } \\
\text { and Water } \\
\text { Utilities } \\
\text { Regulatory } \\
\text { Authority } \\
\text { (EWURA) }\end{array}$ \\
\hline $\begin{array}{l}\text { The central } \\
\text { government } \\
\text { role }\end{array}$ & $\begin{array}{l}\text { The Ministry } \\
\text { of Energy } \\
\text { (MOE) is the } \\
\text { highest body } \\
\text { responsible } \\
\text { for the } \\
\text { functioning } \\
\text { of the } \\
\text { electricity } \\
\text { system. }\end{array}$ & $\begin{array}{l}\text { The Ministry } \\
\text { of Power } \\
\text { (MOP) is } \\
\text { responsible } \\
\text { for energy } \\
\text { related } \\
\text { policy } \\
\text { formulation. }\end{array}$ & $\begin{array}{l}\text { The ministry } \\
\text { of water, } \\
\text { irrigation and } \\
\text { electricity } \\
\text { (MOWIE) } \\
\text { plans, leads, } \\
\text { coordinates, } \\
\text { and monitors, } \\
\text { capacity } \\
\text { building, } \\
\text { research, } \\
\text { development } \\
\text { and } \\
\text { dissemination } \\
\text { of renewable } \\
\text { and improved } \\
\text { energy } \\
\text { technologies. }\end{array}$ & $\begin{array}{l}\text { The } \\
\text { Ministry for } \\
\text { Energy and } \\
\text { Minerals } \\
\text { (Energy } \\
\text { Ministry) is } \\
\text { the highest } \\
\text { body that } \\
\text { has the } \\
\text { mandate to } \\
\text { implement } \\
\text { energy- } \\
\text { related } \\
\text { policies. }\end{array}$ \\
\hline
\end{tabular}

electricity sector, as identified by the actors themselves, include insufficient generation capacity, old and damaged transmission components, lack of human resource capacity, power theft, limited revenue, lack of stakeholder collaboration, lack of consumer awareness on energy efficiency, and poor-quality products. Fig. 2 presents a simplified structure of the on-grid electricity system and its actors in the case-study countries.

4.2.2. Actors and barriers in the off-grid (decentralized) systems New actors continuously emerge to fill the gap in the off-grid 


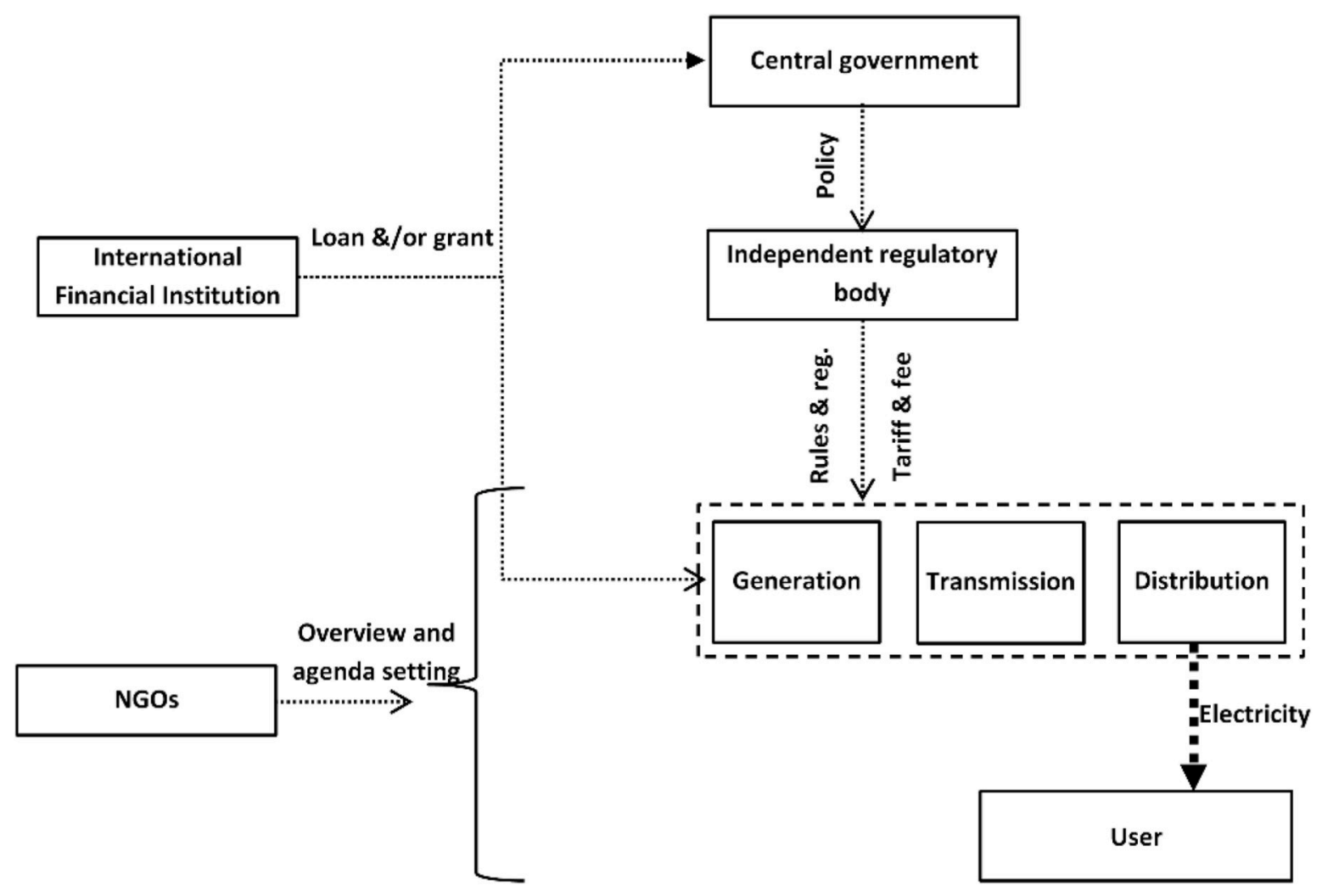

Figure 2. Simplified institutional structure of on-grid electrification.

Table 3

Key actors, institutions and their roles in off-grid electrification.

\begin{tabular}{|c|c|c|c|c|}
\hline $\begin{array}{l}\text { Roles/ } \\
\text { responsibilities }\end{array}$ & Nigeria & Ghana & Ethiopia & Tanzania \\
\hline $\begin{array}{l}\text { Access to working } \\
\text { capital }\end{array}$ & The Central Bank of Nigeria & $\begin{array}{l}\text { The World Bank is the main } \\
\text { source of finance }\end{array}$ & $\begin{array}{l}\text { - Development Bank of Ethiopia } \\
\text { (DBE) } \\
\text { - Rural Electrification Fund (REF) } \\
\text { - The Carbon Initiative for } \\
\text { Development (Ci-Dev) }\end{array}$ & $\begin{array}{l}\text { Rural Energy Agency (REA), African } \\
\text { Development Bank (AfDB) through } \\
\text { SEFA }\end{array}$ \\
\hline $\begin{array}{l}\text { Training and } \\
\text { capacity } \\
\text { building }\end{array}$ & $\begin{array}{l}\text { The Lagos Energy Academy (LEA) and the } \\
\text { National Power Training Institute of Nigeria } \\
\text { (NAPTIN) provide hands-on vocational } \\
\text { training to young specialists in the Power } \\
\text { Sector Value Chain }\end{array}$ & $\begin{array}{l}\text { NGOs together with } \\
\text { government provide trainings } \\
\text { for locals on operation and } \\
\text { maintenance of the system }\end{array}$ & $\begin{array}{l}\text { - Addis Ababa University (AAU) } \\
\text { and Selam Vocational Training } \\
\text { assist in research and capacity } \\
\text { building. } \\
\text { - NGOs are involved in capacity } \\
\text { building of public institutes }\end{array}$ & $\begin{array}{l}\text { National and international } \\
\text { development organizations and NGOs } \\
\text { (i.e. AfDB, GIZ, SNV, the World Bank, } \\
\text { etc.) }\end{array}$ \\
\hline $\begin{array}{l}\text { Advocacy and } \\
\text { awareness }\end{array}$ & $\begin{array}{l}\text { Council for Renewable Energy Nigeria } \\
\text { provides a forum for discussion and } \\
\text { promotes the use of renewable energy } \\
\text { technology for off-grid electrification }\end{array}$ & $\begin{array}{l}\text { NGOs are engaging with local } \\
\text { people and creating } \\
\text { awareness }\end{array}$ & $\begin{array}{l}\text { - The Ethiopian Alternative } \\
\text { Energy Promotion and } \\
\text { Development Centre } \\
\text { - Solar Energy Development } \\
\text { Association (SEDA-E) }\end{array}$ & $\begin{array}{l}\text { Tanzania Renewable Energy } \\
\text { Association (TAREA) works to bring } \\
\text { actors together to promote } \\
\text { accessibility and use of renewable } \\
\text { energy technologies }\end{array}$ \\
\hline Subsidies & $\begin{array}{l}\text { The UK Department for International } \\
\text { Development (DFID) provides fund for co- } \\
\text { financing }\end{array}$ & The Government of Ghana & $\begin{array}{l}\text { The Solar Energy Foundation } \\
\text { (SEF), an NGO, covers } 75 \% \text { of } \\
\text { the cost of a solar home system } \\
\text { for rural households. } \\
\text { - REF also provides capital } \\
\text { subsidy of } 20-30 \% \text { of the } \\
\text { investment costs to renewable } \\
\text { energy project developers. }\end{array}$ & $\begin{array}{l}\text { Rural Energy Agency and Fund (REA/ } \\
\text { F) }\end{array}$ \\
\hline $\begin{array}{l}\text { The role of } \\
\text { government }\end{array}$ & National energy policy, rules and regulations & $\begin{array}{l}\text { Sets the rules and regulations, } \\
\text { facilitated the process and co- } \\
\text { financed the program }\end{array}$ & $\begin{array}{l}\text { Policy and regulation, capacity } \\
\text { building and demonstration } \\
\text { projects }\end{array}$ & $\begin{array}{l}\text { National energy policy, regulations, } \\
\text { licensing \& enforcement }\end{array}$ \\
\hline The private sector & $\begin{array}{l}\text { The global off-grid lighting association } \\
\text { (GOGLA) is involved in electrification with } \\
\text { business models ranging from 'consumer } \\
\text { buying the service' to 'consumer buying the } \\
\text { product' }\end{array}$ & $\begin{array}{l}\text { Installation, operation, and } \\
\text { maintenance of renewable } \\
\text { energy systems }\end{array}$ & $\begin{array}{l}\text { Supply off-grid electrification } \\
\text { technologies }\end{array}$ & $\begin{array}{l}\text { - JUMEME provides solar-diesel } \\
\text { hybrid mini-grids } \\
\text { - Mobisol, Off-grid Electric Tanzania } \\
\text { Ltd. (ZOLA) are involved in providing } \\
\text { solar energy service through pay-as- } \\
\text { you-go models }\end{array}$ \\
\hline $\begin{array}{l}\text { The role of the } \\
\text { community }\end{array}$ & & $\begin{array}{l}\text { On-site support including } \\
\text { facilitation and labour }\end{array}$ & & \\
\hline
\end{tabular}


electrification system in the region. The private sector is gradually growing into the off-grid electricity market, but the institutional and financial capacity problems persist in all case-study countries. Table 3 presents the main actors, institutions and their roles in off-grid electrification in the case-study countries.

There is a growing number of household and community energy producers (and consumers) in all case-study countries. Rural electrification agencies are established in the countries with the mandate to facilitate rapid rural electrification engaging producer-consumers and the private sector. They identify suitable locations and technologies for electrification, advise on tariffs, allocation of subsidies, provide grants, and execute projects. However, most of the actors interviewed expressed their doubts about the possibility of meeting the universal electricity access targets with the current effort. The national electricity policies require better institutional settings and human capacity, as well as greater collaboration between the various actors. Lack of clear policies and targets, institutional barriers (most of all corruption), weak stakeholder collaboration and lack of finance are the four obstacles mentioned repeatedly by respondents for expansion of decentralized systems to provide access. Moreover, lack of institutional capacity, lack of accountability, and high transaction cost are obstacles to progress in the sector. Poor quality counterfeit products (generic solar panels, as they are called by the locals) are also taking advantage of the lack of standards for new technologies reinforcing social barriers. In Ethiopia, the electricity tariffs are amongst the lowest in the world, hindering private sector participation. In addition, the public sector is not communicating with the private sector, which results in sub-optimal outcomes. There is no clear role for donors and NGOs. Fig. 3 presents a simplified structure of the off-grid electricity system and its actors in the case-study countries.

\subsection{Existing regulatory instruments to stimulate off-grid systems}

The case-study countries have developed several regulatory instruments to address the barriers listed in Section 2.3, including financial incentives (e.g. start-up grant, loan guarantee), fiscal incentives (e.g. exemption of import duty and/or value added tax), and elimination of market distortions (e.g. reducing fossil fuel subsidies) (see Table 4). Government grants are often provided to reduce the relatively high costs of renewable energy technologies that are still unaffordable for many consumers. Capital subsidy is one of the most widely adopted policy instruments to help off-grid projects overcome the initial investment barrier. In Ethiopia, the Solar Energy Foundation (SEF) provided 75\% of the fund for a solar home system in rural settlements while the rest of the investment was covered by the beneficiary. The government of Ethiopia also provides duty exemptions for importing solar power related equipment. In Ghana, the government subsidized the cost of PV modules up to 500 Watt to beneficiaries of the national rooftop solar program, whereby the beneficiary purchases the rest of the balance of system (BoS) components such as batteries, inverter and charge controller.

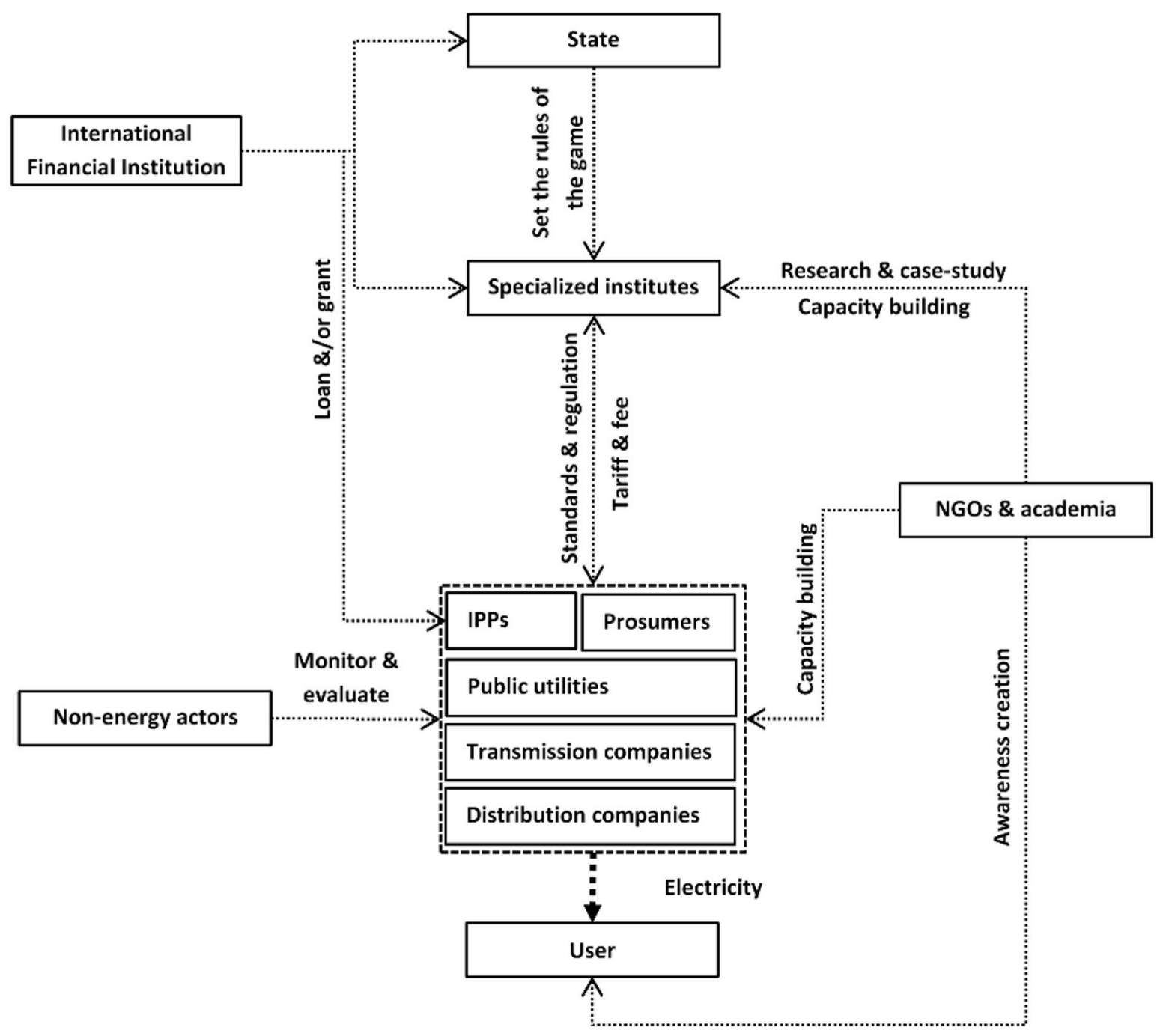

Fig. 3. Simplified institutional structure of off-grid electrification systems. 
Table 4

Summary of regulatory measures in the case-study countries to overcome the challenges of decentralized renewable energy systems.

\begin{tabular}{|c|c|c|c|c|c|}
\hline & \multirow[t]{2}{*}{ Challenge } & \multicolumn{4}{|l|}{ Regulatory measure } \\
\hline & & Nigeria & Ghana & Ethiopia & Tanzania \\
\hline 1 & Market failure & $\begin{array}{l}\text { - The EPSR Act } \\
\text { - Partial unbundling and } \\
\text { Privatization } \\
\text { - Exempting power projects of } \\
\text { under 1MW from obtaining } \\
\text { license }\end{array}$ & $\begin{array}{l}\text { - Partial unbundling } \\
\text { - Establish competitive wholesale } \\
\text { electricity market }\end{array}$ & - Partial unbundling & \\
\hline 2 & Market distortion & - Import duty exemption & - Import duty exemption & $\begin{array}{l}\text { - Gradually eliminating fossil fuel } \\
\text { subsidies } \\
\text { - Import duty exemption }\end{array}$ & - Import duty exemption \\
\hline 3 & $\begin{array}{l}\text { Economic and } \\
\text { financial barriers }\end{array}$ & $\begin{array}{l}\text { - Capital incentives ( } 50 \% \text { of } \\
\text { the initial investment) } \\
\text { - Preferential loan Value added } \\
\text { tax exemptions } \\
\text { - Rural tariff model with higher } \\
\text { margins than urban projects } \\
\text { - Special fund } \\
\text { - Micro-finance }\end{array}$ & $\begin{array}{l}\text { - Capital subsidy to cover the cost } \\
\text { of solar PV modules (up to } 500 \\
\text { W) } \\
\text { - Preferential loan } \\
\text { - Purchase obligations } \\
\text { - Value added tax exemptions } \\
\text { Special fund } \\
\text { - Micro-finance }\end{array}$ & $\begin{array}{l}\text { - Capital incentives ( } 75 \% \text { of the } \\
\text { initial investment) } \\
\text { - Preferential loan ( } 0 \% \text { interest rate } \\
\text { for renewable energy projects) } \\
\text { - Value added tax exemptions } \\
\text { - Special fund (Rural Electrification } \\
\text { Fund) } \\
\text { - Micro-finance } \\
\text { - Subsidies }(20-30 \% \text { of CAPEX) }\end{array}$ & $\begin{array}{l}\text { - Capital Subsidy (SNV's Results } \\
\text { Based Financing, 1.5\$-2.5\$/Wp } \\
\text { for SHS) } \\
\text { - Preferential loan } \\
\text { - Value added tax exemptions } \\
\text { - Special fund } \\
\text { - Micro-finance }\end{array}$ \\
\hline 4 & Institutional barriers & $\begin{array}{l}\text { - Established specialized } \\
\text { institutions } \\
\text { - Regulatory authority }\end{array}$ & $\begin{array}{l}\text { - Established specialized institutes } \\
\text { - Regulatory authority }\end{array}$ & $\begin{array}{l}\text { - Established specialized institutes } \\
\text { - Regulatory authority }\end{array}$ & $\begin{array}{l}\text { - Established specialized institutes } \\
\text { - Regulatory authority }\end{array}$ \\
\hline 5 & Technical barriers & $\begin{array}{l}\text { - Lagos Energy Academy (LEA) } \\
\text { - National Power Training } \\
\text { Institute of Nigeria (NAPTIN) }\end{array}$ & $\begin{array}{l}\text { - Certification program-Certified } \\
\text { Electrical Wiring Professionals } \\
\text { (CEWPs) }\end{array}$ & $\begin{array}{l}\text { - Solar technology training centre } \\
\text { - International Solar Energy School }\end{array}$ & \\
\hline 6 & $\begin{array}{l}\text { Social, cultural and } \\
\text { behavioural barriers }\end{array}$ & $\begin{array}{l}\text { - Sell energy services instead of } \\
\text { energy products }\end{array}$ & $\begin{array}{l}\text { - Monitoring and inspection by } \\
\text { government officials of installed } \\
\text { products }\end{array}$ & $\begin{array}{l}\text { - Awareness creation through pilot } \\
\text { projects by NGOs and academic } \\
\text { institutes }\end{array}$ & $\begin{array}{l}\text { - Awareness creation through pilot } \\
\text { projects by NGOs and academic } \\
\text { institutes }\end{array}$ \\
\hline
\end{tabular}

Several banks have expressed interest in providing loan facilities for the purchase of BOS components. Solar PV projects in Nigeria and Tanzania receive tax exemptions to soften the burden of the initial investment.

In some cases, special funds were set up to broaden financing channels for off-grid projects, and preferential interest rates were provided for loans for off-grid renewable energy development to deal with economic and financial barriers. In Tanzania, the Rural Energy Fund (REF) was established to provide grants to developers of rural energy projects and to utilities for rural grid distribution investments. In Ghana, the Scaling-up Renewable Energy Investment Plan (SREP-IP) under the Climate Investment Fund provides large loans for renewable energy projects. Similarly, in Ethiopia, the Development Bank of Ethiopia (DBE) that, in partnership with the International Development Association (IDA) under the Electricity Network Reinforcement and Expansion Project (ENREP) of the World Bank, is providing working capital loans to private sector providers and micro-finance to households. Solar crowdfunding is a new financing mechanism in which investment funds in solar systems are raised from individual investors through the internet, such as TRINE in Tanzania and Uganda. Operating \& maintenance subsidies are seen as essential to sustain the project operations over a long period, particularly in the case of extremely remote areas with a poor ability to pay. Micro-finance to rural households for SolarHome-Systems has been successfully implemented in Ethiopia. Table 4 presents the different regulatory measures implemented or being implemented in the case-study countries to address some of the challenges to wider deployment of renewable energy based decentralized systems discussed in section 2.3 .

\section{Discussion}

In this study we aimed to provide relevant policy recommendations to facilitate universal electricity access in SSA. Our approach combined desk research, iterative discussions with experts, and stakeholder interviews in four case-study countries. First, an overview of the institutional transformation required to tackle the barriers to wider deployment of decentralized electrification systems has been generated. Next, a set of alternative storylines was developed in expert workshop to explore the evolving role of old and new actors in the electricity system. We also identified the relevant actors and explored their perspectives on the challenge for universal electricity access and the role of decentralized systems in SSA. Finally, we have identified regulatory measures in the case-study countries that are implemented to overcome these barriers. We have not explored if these measures are economically optimal solutions, nor what their effects on other sectors of the economy could be.

Despite the social and economic differences of our case-study countries, there is little difference in the development of the power sector. In all the case-study countries, the system is similar to what is described under storyline-1: structured top-down with little room for new players. This system has not been able to increase access at the scale required to achieve the universal access target. A slow transformation to what is described under storyline- 2 takes place to accommodate new actors and their resources. However, the pace of this transformation has been very slow. While generation, transmission and distribution are unbundled in all countries, it is only in Nigeria where power generation within the central grid is privatised. Decentralized off-grid options provided through specialized institutions such as rural electrification agencies are growing in importance in all countries. These institutions facilitate the expansion of the systems through market development involving private sector and other stakeholders. Several regulatory instruments are employed by governments to tackle the barriers for increasing access to electricity, ranging from financial incentives to restructuring of the electricity governance at all levels.

Considering the urgency of the matter, bottom-up decentralized electrification is ideal for accelerating universal access to electricity in poor rural areas. However, the institutional structure still lacks incentives for innovations in technology and business model to improve access at the speed required to achieve the universal access target. The regulatory agencies not only have limited capacity but also lack political independence. In most cases, there is no clear role for community organizations, donors, academic institutions and NGOs. Despite the ongoing reform, institutional and economic barriers will, at least in the short and medium term, hinder the progress in renewable energy technology deployment and, hence, universal electricity access in SSA. 
From the desk research and stakeholder interviews, we identify lack of overarching plans and approaches, lack of clarity in policies, and counterfeit products as major barriers that imped the expansion of decentralized systems. In addition, high up-front costs for consumers, a lack of access to finance for the private sector and consumers, a lack of awareness about renewable energy technology, lack of standards for new technologies, lack of coordination and cooperation between various actors, and high transaction costs are also identified as common barriers. Previous studies show that, if universal electricity access is to be achieved, much is expected from distributed renewable energy generation. This need for and the potentials of renewable energy technologies to achieve universal electricity access is recognized by private and public actors alike, but realizing the potential requires a much more radical change in the institutional settings of the energy sector in SSA.

\section{Conclusion and policy implications}

From our desk research, expert workshops and stakeholder interviews, we draw the following conclusion and policy recommendations:

Upscaling off-grid systems requires stable and consistent policy frameworks and clear technical standards and certification for new technologies. The results of the desk research and the stakeholder interviews demonstrate that the absence of overall plan and approach, lack of clarity in policies, and counterfeit products are the most common barriers shared by public and private actors and consumers. Achieving universal electricity access requires better collaboration and coordination between stakeholders to align data, finance and governance efforts. In our case-study countries, however, the public sector lacks sufficient capacity (as observed in rural electrification agencies) to design policies, establish standards and monitor the process. Therefore, improved coordination between actors could increase the synergy of the various electrification programs and save resources.

Achieving universal access to electricity through the integration of off-grid systems requires innovative revenue schemes, financial and fiscal incentives and elimination of market distortions. Addressing the financial capacity problem identified by the interviewees requires a broader participation of non-governmental actors. Private sector participation in both the central and decentralized systems in our case-study countries is limited. Increasing participation of non-governmental actors requires differentiated financing schemes, such as public private partnerships, participation of community-interest companies, and low-profit and for-benefit corporations working together. Stable and transparent policies and government support are important to encourage the private sector. At the same time, lowering the transaction cost by making reliable data for weather, household consumption, and ability to pay readily available, could stimulate the private sector participation.

Stakeholders could facilitate low interest loans to stimulate the development of decentralized electricity systems, but at the risk of leading to corruption. As showed by the results of the stakeholder interviews, fiscal incentives are the preferred stimulation package by governments of our case-study countries. These incentives represent a major component of public policies to stimulate off-grid electrification. All the case-study countries provide exemptions for import tax and value-added tax for renewable energy technologies. Providing loans at preferential interest rates compared to the market can help stimulate access to electricity and the dissemination of renewable energy technology. However, these instruments are not yet well developed and can lead to corruption and inefficient bureaucracies.

\section{Future work}

The next step is to translate the qualitative storylines and the governance instruments identified in this study to a quantitative simulation model.

\section{Declaration of competing interest}

The authors declare that they have no known competing financial interests or personal relationships that could have appeared to influence the work reported in this paper.

\section{CRediT authorship contribution statement}

Anteneh G. Dagnachew: Conceptualization, Methodology, Formal analysis, Investigation, Writing - original draft, Writing - review \& editing. Andries F. Hof: Supervision, Funding acquisition, Writing review \& editing. Mark R. Roelfsema: Writing - review \& editing. Detlef P. van Vuuren: Supervision, Funding acquisition, Writing - review \& editing.

\section{Acknowledgements}

The authors would like to thank Prof. dr.ir. Eefje H.W.J. Cuppen (Professor of Governance of Sustainability at Leiden University) who provided valuable contribution to the research methodology. We are also grateful for Professor Peter Newell (Professor of International Relations at the University of Sussex) and Professor Harriet Bulkeley (professor in the Department of Geography at the University of Durham) for their participation in the workshops, their valuable comments to the content of this manuscript and the contribution of their 'The Rising Powers' project to this article. We also thank Paul L. Lucas (senior researcher at PBL Netherlands Environmental Agency) for his comments in the earlier versions of the paper that greatly improved this manuscript.

The research presented in this paper was funded by the Dutch Ministry of Foreign Affairs, through its Directorate-General of Trade and International Cooperation. The work also benefitted from the funding of the European Horizon 2020 research programme CD-LINKS [grant agreement No 642147].

\section{Appendix A. Supplementary data}

Supplementary data to this article can be found online at https://doi. org/10.1016/j.enpol.2020.111572.

\section{References}

Aliyu, A.S., Ramli, A.T., Saleh, M.A., 2013. Nigeria electricity crisis: power generation capacity expansion and environmental ramifications. Energy 61, 354-367.

APP, 2015. Power, People, Planet: Seizing Africa's Energy and Climate Opportunities Africa Progress Panel.

Azerefegn, T.M., Bhandari, R., Ramayya, A.V., 2020. Techno-economic analysis of gridintegrated PV/wind systems for electricity reliability enhancement in Ethiopian industrial park. Sustainable Cities and Society 53.

Baker, L., Newell, P., Phillips, J., 2014. The political economy of energy transitions: the case of South Africa. New Polit. Econ. 19 (6), 791-818. https://doi.org/10.1080/ 13563467.2013 .849674$.

Bhattacharyya, S.C., 2013. Financing energy access and off-grid electrification: a review of status, options and challenges. Renew. Sustain. Energy Rev. 20, 462-472.

Chaurey, A., Kandpal, T.C., 2010. Assessment and evaluation of PV based decentralized rural electrification: an overview. Renew. Sustain. Energy Rev. 14, 2266-2278.

Clean, 2015. Unlocking access to finance for decentralized energy solutions. CLEAN Strategy Series. https://www.thecleannetwork.org/wp-content/uploads/2018/06/ unlocking-access-to-finance.pdf.

Dagnachew, A.G., Lucas, P.L., Hof, A.F., Gernaat, D.E.H.J., DE Boer, H.-S., VAN Vuuren, D.P., 2017. The role of decentralized systems in providing universal electricity access in Sub-Saharan Africa - a model-based approach. Energy 139, 184-195.

Dagnachew, A.G., Lucas, P.L., Hof, A.F., VAN Vuuren, D.P., 2018. Trade-offs and synergies between universal electricity access and climate change mitigation in SubSaharan Africa. Energy Pol. 114, 12.

Deshmukh, R., Carvallo, J.P., Gambhir, A., 2013. Sustainable Development of Renewable Energy Mini-Grids for Energy Access: A Framework for Policy Design. The University of California, Berkeley.

Eberhard, A., Gratwick, K., Morella, E., Antmann, P., 2016. Independent Power Projects in Sub-saharan Africa: Lessons from Five Key Countries. World Bank, Washington, Dc. 
Gujba, H., Thorne, S., Mulugetta, Y., Rai, K., Sokona, Y., 2012. Financing low carbon energy access in Africa. Energy Pol. 47, 71-78.

Gyamfi, S., Amankwah Diawuo, F., Nyarko Kumi, E., Sika, F., Modjinou, M., 2018. The energy efficiency situation in Ghana. Renew. Sustain. Energy Rev. 82, 1415-1423.

Hoogwijk, M., 2004. On the Global and Regional Potential of Renewable Energy Sources. Doctoral Doctoral Thesis. Utrecht University.

Hussain, M.Z., 2013. Financing Renewable Energy Options for Developing Financing Instruments Using Public Fund. World Bank, Washington DC.

IEA, 2014. Africa Energy Outlook. A Focus on Energy Prospects in Sub-saharan Africa. World Energy Outlook Special Report. International Energy Agency, Paris, France.

IEA, 2017. Energy Access Outlook 2017: from Poverty to Prosperity. IEA, Paris.

IEA, 2019. World Energy Outlook 2019. International Energy Agency.

IRENA, 2012. Prospects for the African Power Sector: Scenarios and Strategies for Africa Project. International Renewable Energy, Abu Dhabi.

Joskow, P.L., 2006. Introduction to electricity sector liberalization: lessons learned from cross-country studies. In: Sioshansi, F.P., Pfaffenberger, W. (Eds.), Electricity Market Reform: an International Perspective. Elsevier.

Koirala, B.P., Koliou, E., Friege, J., Hakvoort, R.A., Herder, P.M., 2016. Energetic communities for community energy: a review of key issues and trends shaping integrated community energy systems. Renew. Sustain. Energy Rev. 56, 722-744.

Lammers, I., Diestelmeier, L., 2017. Experimenting with law and governance for decentralized electricity systems: adjusting regulation to reality? Sustainability 9 , 14.

Moula, M.M.E., Maula, J., Hamdy, M., Fang, T., Jung, N., Lahdelma, R., 2013. Researching social acceptability of renewable energy technologies in Finland. International Journal of Sustainable Built Environment 2, 89-98.

Newell, P., Phillips, J., 2016. Neoliberal energy transitions in the South: Kenyan experiences. Geoforum 74, 39-48.

Pachauri, S., Brew-Hammond, A., 2012. Energy access for development. In: Sathaye, J. (Ed.), The Global Energy Assessment- toward a Sustainable Future. Cambridge University Press, Cambridge.

Parshall, L., Pillai, D., Mohan, S., Sanoh, A., Modi, V., 2009. National electricity planning in settings with low pre-existing grid coverage: development of a spatial model and case study of Kenya. Energy Pol. 37, 2395-2410.

Power, M., Newell, P., Baker, L., Bulkeley, H., Kirshner, J., Smith, A., 2016. The political economy of energy transitions in Mozambique and South Africa: the role of the Rising Powers. Energy Research \& Social Science 17, 10-19.

Rai, N., Best, S., Soanes, M., 2016. Unlocking Climate Finance for Decentralized Energy Access. Working Paper. Intenrnational Insitute for Environment and Development, London.
Scott, A., 2015. Building Electricity Supplies in Africa for Growth and Universal Access Background Paper for Power, People, Planet: Seizing Africa's Energy and Climate Opportunities. D.C: New Climate Economy, London and Washington.

Scott, A., Seth, P., 2013. The Political Economy of Electricity Distribution in Developing Countries: A Review of the Literature. Overseas Development Institute, London.

Shi, X., Liu, X., Yao, L., 2016. Assessment of instruments in facilitating investment in offgrid renewable energy projects. Energy Pol. 95, 437-446.

Sokona, Y., Mulugetta, Y., Gujba, H., 2012. Widening energy access in Africa: towards energy transition. Energy Pol. 47, 3-10.

Tagliapietra, S., Bazilian, M., 2017. The role of international institutions in fostering sub - saharan Africa's electrification. Columbia SIPA- Center on Global Energy Policy.

Tenenbaum, B., Greacen, C., Siyambalapitiya, T., Knuckles, J., 2014. From the Botton up: How Small Power Producers and Mini-Grids Can Deliver Electrification and Renewable Energy in Africa. nternational Bank for Reconstruction and Development/The World Bank, Washington Dc.

Turkson, J., Wohlgemuth, N., 2001. Power sector reform and distributed generation in sub-Saharan Africa. Energy Pol. 29, 12.

Wade, J., Eyre, N., Hamilton, J., Parag, Y., 2013. Local energy governance: communities and energy efficiency policy (3-031-13). In: Sweden, S. (Ed.), THERESE LAITINEN LINDSTRÖM BORG \& Co. ECEEE 2013 Summer Study - Rethink, renew, restart, Belambra Les Criques, Toulon/Hyères, France, p. 12.

Winkler, B., Lemke, S., Ritter, J., Lewandowski, I., 2017. Integrated assessment of renewable energy potential: approach and application in rural South Africa. Environmental Innovation and Societal Transitions 24, 17-31.

Whitley, S., van der Burg, L., 2015. Fossil Fuel Subsidy Reform in Sub-Saharan Africa: From Rhetoric to Reality. New Climate Economy, London and Washington, DC. Available at. http://newclimateeconomy.report/misc/working-papers. https ://newclimateeconomy.report/workingpapers/wp-content/uploads/sites /5/2016/04/FFS-Reform-in-Africa_NCE-ODI_final.pdf.

Winkler, H., 2005. Renewable energy policy in South Africa: policy options for renewable electricity. Energy Pol. 33, 27-38.

World Bank, 2009. Deterring Corruption and Improving Governance in the Electricity Sector. The World Bank, Washington DC.

World Bank, 2017. World Bank open data [online]. Available: http://data.worldbank.or g/indicator/EG.USE.ELEC.KH.PC. Accessed 7-4-2016 2016.

Yaqoot, M., Diwan, P., Kandpal, T.C., 2016. Review of barriers to the dissemination of decentralized renewable energy systems. Renew. Sustain. Energy Rev. 58, 477-490. 